\title{
梁に压着接合した壁パネル付き耐震壁の 最大耐力に関する解析的研究
}

\author{
柳沢学*1 望月 重 ${ }^{* 2}$ ・東浦章*3 ・斎藤 文孝*4
}

\begin{abstract}
概 要 本研究は, プレキャスト壁パネルを柱と接合することなしに，架構上下の梁にプレストレスを利用して接合した壁 パネルが組み込まれた耐震壁の最大耐力について解析的に検討したものである。検討対象は, 壁パネルの単体実験の試験体お よび架構に組み込まれた耐震壁の試験体である。解析モデルの特徴は, 壁パネルの水平接合部に実験結果より求めたすべりの 変形の増大とともに生じる付加軸力を考慮した履歴モデルを用いていることである。解析は, 水平接合部ですべり破壊するも の, 壁パネル中央の開口のために残された部分が曲げ破壊するものおよび壁パネルがせん断破壊するものの 3 種類の壁パネル の破壊形式を最大耐力とともに追跡できることが認められた。

キーワード : プレキャストコンクリート壁パネル, プレストレス, 耐震壁, FEM 解析, すべりのモデル化
\end{abstract}

\section{1.はじめに}

筆者らは，壁パネルをプレキャスト $(\mathrm{PCa})$ 化し，柱 との接合を省いて壁パネル上下の梁とは $\mathrm{PC}$ 鋼棒を利用 して接合する工法を提案した ${ }^{1)}$ 。本工法は, 地震時水平 力に対して任意の剛性および耐力を設定できるように考 案したものである。耐震壁の剛性は壁パネルの長さや厚 さ等を調整することにより, またその耐力は $\mathrm{PC}$ 鋼棒に よる導入軸方向力や $\mathrm{PC}$ 鋼棒の連結の有無などを調整す ることにより任意の耐力に対応できるようにしている。

提案している工法では, 大地震に対しては壁パネルに 損傷が集中するようにし, 周辺の架構の損傷は軽微なも のとする。特に柱は曲げ降伏としている。地震後は損傷 が大きい壁パネルを取り換えることにより, 地震前の構 造性能を復元させることを意図としている。

しかし,この工法では, 側柱と壁パネルを接合してい ないことや壁パネルの上下に PC 鋼棒による圧着接合部 が存在することから, 耐震壁の設計では, 架構を介して $\mathrm{PC}$ 鋼棒により導入される壁パネルへのプレストレスカ や壁パネルを拘束する架構の剛性および耐力などの影響 を考慮に入れなければならない。筆者らは, 既に, 一層 の架構に組み入れた壁パネル単体および耐震壁の実験を

\footnotetext{
$* 1$ 佐藤工業(㑣)中央技術研究所建築研究部門 建築構法グ ループ長（正会員）

*2 武蔵工業大学教授 工学部建築学科 (正会員)

*3 佐藤工業(㑣)中央技術研究所 建築研究部門長 (正会員)

* 4 佐藤工業(侏東京支店
}

行い, 壁パネルの耐力をその破壊形式とともに推定でき ることを確認している1) 4)。

本研究は, 壁パネルを組み入れた耐震壁の最大耐力に ついて有限要素法 (以下, FEM 解析之略) による解析 的な検討を行い, すでに終了した実験結果を主に破壊形 式および最大耐力について追跡し, 本 FEM 解析手法の 実用性について検討したものである。

\section{2. 解析 概 要}

\section{1 解析対象}

FEM 解析対象とした試験体は, 壁パネル単体実験の 試験体 $^{2)}$,3) および壁パネルを架構に組み込んだ耐震壁 の試験体 ${ }^{4)}$ である。

解析対象とした試験体の諸元一覧を表-1 に, 耐震壁 試験体の形状・寸法および配筋状況を図-1に示す。

壁パネル単体実験の結果, 壁パネルの破壊形式は大き く4 通りに分けられる。すなわち, 壁パネル水平接合部 ですべり破壊を生じるもの (No. 3), 壁パネルがせん断 破壊するもの (No. 2), 壁パネル中央の PC 鋼棒定着開 口間の壁（以下，壁柱部）が曲げ破壊するもの（No. 17), および壁パネル脚部コンクリートが曲げ圧壊する もの (No. 5) である。ただし, No. 3, No. 2 およびNo. 17 は逆対称曲げせん断型の加力方法を行ったものであ り, No. 5 は片持ち梁形式の曲げ型加力を行ったもので ある。壁パネル単体実験では，これらの破壊形式を代表 する試験体を対象に FEM 解析を行う。耐震壁の解析で は，5体の試験体すべてについて解析を行う。 
表-1 解析対象試験体一覧

\begin{tabular}{|c|c|c|c|c|c|c|c|c|}
\hline \multirow{2}{*}{ 対象種別 } & \multirow{2}{*}{ 試験体名 } & \multicolumn{2}{|c|}{ プレストレスレベル } & \multirow{2}{*}{$\begin{array}{l}\text { 壁パネル } \\
\text { 断面 積 }\end{array}$} & \multirow{2}{*}{$\begin{array}{c}\text { 定着開口寸法法 } \\
\text { 数 } \times \text { 高さ } \\
(\mathrm{mm})\end{array}$} & \multirow{2}{*}{$\begin{array}{l}\mathrm{PC} \text { 鋼棒 } \\
\text { 本数と径 }\end{array}$} & \multirow{2}{*}{ 架構種別 } & \multirow{2}{*}{ 加力方法 } \\
\hline & & 接合部 & 壁パネル & & & & & \\
\hline \multirow{4}{*}{$\begin{array}{l}\text { 壁パネル } \\
\text { 単 体 }\end{array}$} & No. 2 & \multirow{3}{*}{\multicolumn{2}{|c|}{$\begin{array}{c}40 \mathrm{kgf} / \mathrm{cm}^{2} \\
(3.9 \mathrm{MPa})\end{array}$}} & $846 \mathrm{~cm}^{2}$ & $4-100 \times 350$ & \multirow{3}{*}{$4-17 \phi$} & & \multirow{2}{*}{ 逆対称型 } \\
\hline & No. 3 & & & \multirow{2}{*}{$864 \mathrm{~cm}^{2}$} & \multirow{2}{*}{ 無し } & & & \\
\hline & No. 5 & & & & & & & 曲げ型 \\
\hline & No. 17 & $\begin{array}{c}40 \mathrm{kgf} / \mathrm{cm}^{2} \\
(3.9 \mathrm{MPa})\end{array}$ & $0^{* * *}$ & $963 \mathrm{~cm}^{2}$ & $4-100 \times 800^{*}$ & $4-17 \phi^{* *}$ & & 逆対称型 \\
\hline \multirow{5}{*}{ 耐 震 壁 } & No. F 3 & \multirow{2}{*}{\multicolumn{2}{|c|}{$\begin{array}{l}40 \mathrm{kgf} / \mathrm{cm}^{2} \\
(3.9 \mathrm{MPa})\end{array}$}} & \multirow{5}{*}{$963 \mathrm{~cm}^{2}$} & \multirow{2}{*}{ 無し } & \multirow{2}{*}{$4-17 \phi$} & 架構 1 & \multirow{5}{*}{$\begin{array}{c}\text { 上部梁への } \\
\text { 加力 }\end{array}$} \\
\hline & No. FR 3 & & & & & & 架構 2 & \\
\hline & No. F 18 & $\begin{array}{c}40 \mathrm{kgf} / \mathrm{cm}^{2} \\
(3.9 \mathrm{MPa})\end{array}$ & $0^{* * *}$ & & $4-100 \times 640^{*}$ & $4-17 \phi^{* *}$ & 架構 1 & \\
\hline & No. F 19 & \multirow{2}{*}{\multicolumn{2}{|c|}{$\begin{array}{l}40 \mathrm{kgf} / \mathrm{cm}^{2} \\
(3.9 \mathrm{MPa})\end{array}$}} & & \multirow{2}{*}{$4-100 \times 640^{*}$} & \multirow{2}{*}{$4-17 \phi$} & & \\
\hline & No. FR 19 & & & & & & 架構 2 & \\
\hline
\end{tabular}

*: 開ログラウト充午無し $* *: \mathrm{PC}$ 鋼棒非連結 $* * *$ : 壁柱部にはプレストレスカは非載荷

共通 壁パネル 長さ: 2000 高さ : 1600 厚さ: 90 配筋 : D $6 @ 100 \mathrm{D}(\mathrm{pw}=0.71 \%)$

壁柱部 主筋 : 4-D $10(\mathrm{pg}=0.99 \%)$ 帯筋 : 2-D 6 @ $100(\mathrm{pw}=0.71 \%)$

X型筋 : 2-D 16 (No. 17, No. F 18, No. F 19, No. FR 19)

開口補強＼cjkstart壁柱部に X 状に D 6 を配筋 (No. 2)

架構 架構 1 柱 $40 \mathrm{~cm} \times 40 \mathrm{~cm}$ 主筋 : 8-D $16 \quad \mathrm{pg}=1.0 \% \quad$ 帯筋 : 3-D $6 @ 50 \quad \mathrm{pw}=0.48 \%$

梁 $22.5 \mathrm{~cm} \times 40 \mathrm{~cm}$ 主筋 : 10-D $16 \mathrm{pt}=0.88 \%$ 肋筋 : $3-\mathrm{D} 6 @ 50 \mathrm{pw}=0.85 \%$

架構 2 柱 $40 \mathrm{~cm} \times 40 \mathrm{~cm}$ 主筋 : $16-\mathrm{D} 16 \mathrm{pg}=2.0 \%$ 帯筋 : 4-D 6 @ $50 \quad \mathrm{pw}=0.64 \%$

梁 $25 \mathrm{~cm} \times 40 \mathrm{~cm}$ 主筋 : 6-D $19 \quad \mathrm{pt}=0.96 \%$ 肋筋 : 2-D $10 @ 50$ (1-D 19 X 型筋)

$\mathrm{pw}=1.14 \%$

なお, No. F 19 は No. F 3 の, No. FR 19 はNo. FR 3 の実験終了後の架構を用いて壁パネルのみ新しいも のに取り換えた試験体である

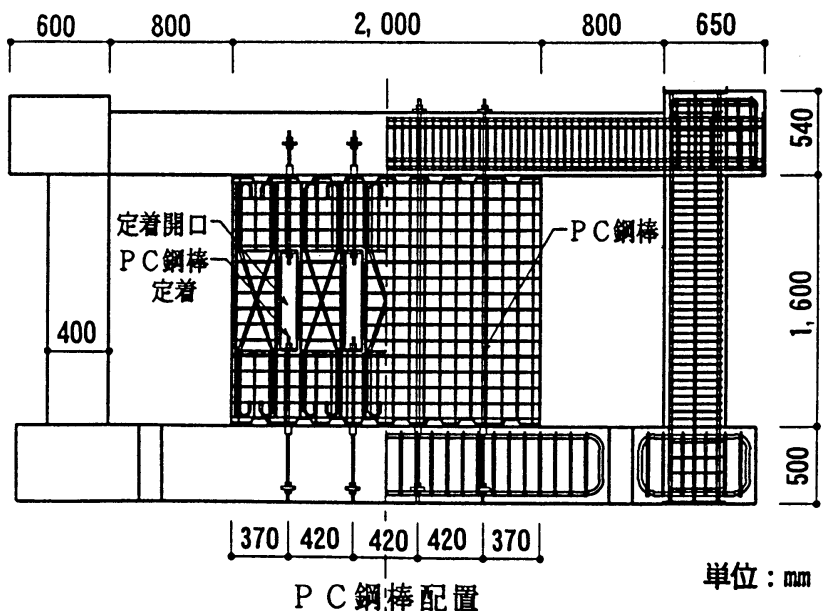

No. F18

P C 鋼棒配置

No. F3

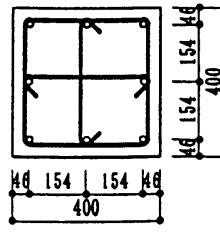

柱断面

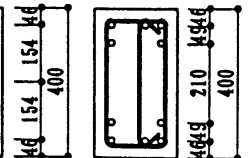

48904348

梁断面

架構 1

\section{요

単位 : mm 


\section{2 解析モデルおよび解析方法}

FEM 解析では, 壁パネルが平面応力状態にあるもの とし，コンクリートおよび鉄筋の材料非線形性を以下の ようにモデル化して解析した。ただし，以下のコンク リートのモデルについては文献5)にその詳細が示されて おり本論文において提案するものではない。特に，本論 文では，繰返し加力による鉄筋のひずみ硬化の影響およ
び壁パネルとスタブあるいは梁の水平接合部の挙動につ いて，実験結果を基にモデル化して取り入れたところに 特徴がある。

（1）コンクリート

コンクリートは, 図-2に示すように，4節点アイソ パラメトリック要素で構成され, 構成則は二軸応力下の コンクリートの非線形挙動をよく表現できるとされてい

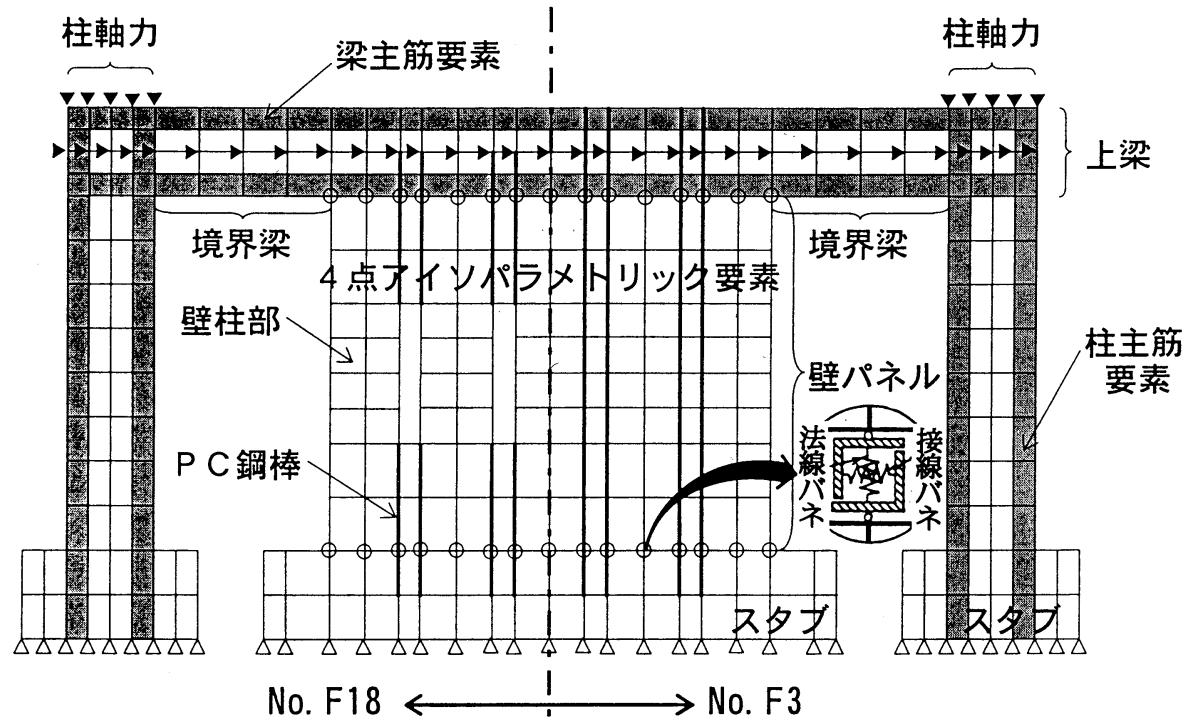

図-2 解析モデル
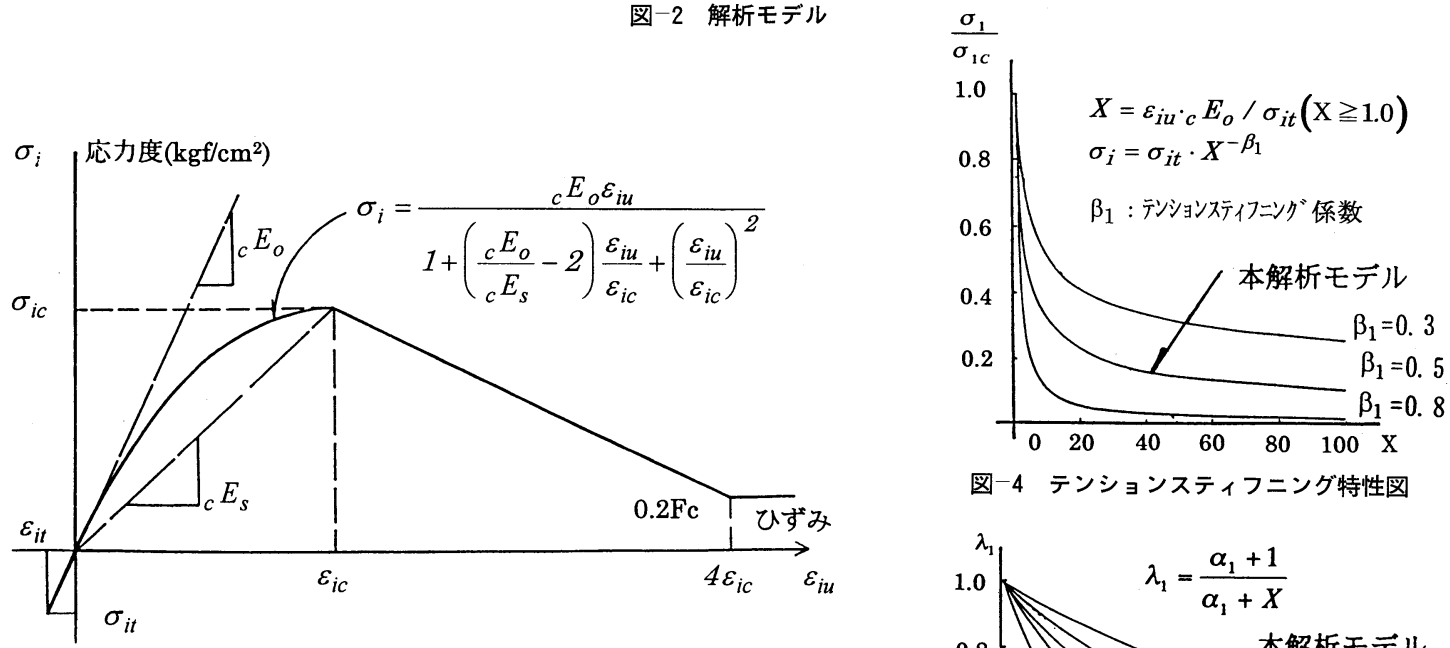

図-4 テンションスティフニング特性図

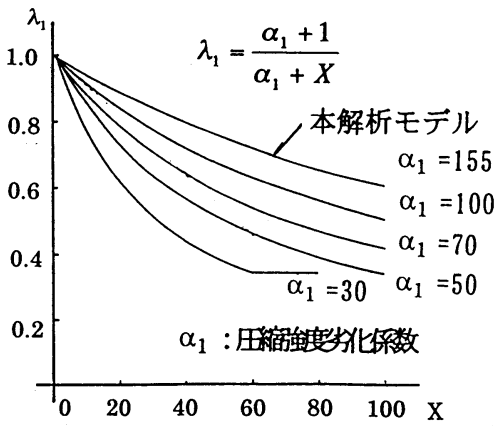

図-5 ひび割れに伴う圧縮強度の劣化特性 
るDarwin 等による直交異方性モデル 6$)$ を用い，等価 一軸ひずみとして武藤博士等による有効ひずみ ${ }^{7)}$ を用い た。図-3に示すように主応力と有効ひずみの関係は, 引張側ではひび割れ発生まで弾性とし，ひび割れ発生後 は鉄筋との付着によるテンションスティフニング効果を 考慮し、ひずみレベルに応じて除々に応力を低減した (図-4 参照)。また，圧縮側は圧縮強度にいたるまでは Saenz 式8)を用い，それ以降の軟化域はその負勾配を直 線と仮定した。ひび割れ面での骨材のかみ合いによるせ ん断伝達は,ひび割れ幅に応じてせん断剛性を低減させ る Cervenka のモデル9)を用いた。ひび割れに伴うコン クリート圧縮強度の劣化係数を図 -5 に示す。

コンクリートの破壊条件は図-6 に示すように, Kupfer 等 ${ }^{10)}$ による破壊条件式を用いたが，ひび割れ 発生後のコンクリートの圧縮強度は Collins 等の実験結

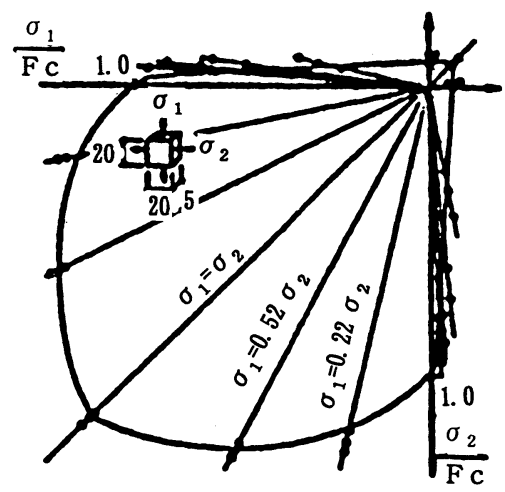

図-6 コンクリートの破壊条件

表 -2 材料特性

（1）コンクリートの特性

(a) 壁パネル単体実験

\begin{tabular}{c|c|c|c}
\hline 試験体名 & $\begin{array}{c}\text { 厌縮強度 } \sigma_{B} \\
\left(\mathrm{kgf} / \mathrm{cm}^{2}\right)\end{array}$ & $\begin{array}{c}\text { 割裂強度 } \sigma_{t} \\
\left(\mathrm{kgf} / \mathrm{cm}^{2}\right)\end{array}$ & $\begin{array}{c}\text { ヤング係数 } E_{c} \\
\left(10^{5} \mathrm{kgf} / \mathrm{cm}^{2}\right)\end{array}$ \\
\hline No. 2 & $311(30.5 \mathrm{MPa})$ & $13.5(1.32 \mathrm{MPa})$ & $2.15(21.0 \mathrm{GPa})$ \\
\hline No. 3 & $355(34.8 \mathrm{MPa})$ & $13.5(1.32 \mathrm{MPa})$ & $2.43(23.8 \mathrm{GPa})$ \\
\hline No. 5 & $356(34.9 \mathrm{MPa})$ & $14.0(1.37 \mathrm{MPa})$ & $2.32(22.7 \mathrm{GPa})$ \\
\hline No. 17 & $423(41.5 \mathrm{MPa})$ & $15.5(1.52 \mathrm{MPa})$ & $2.02(19.8 \mathrm{GPa})$ \\
\hline
\end{tabular}

（）内の数值はSI 単位系で表したものである。

(b) 耐震壁実験

\begin{tabular}{|c|c|c|c|c|}
\hline & 部 & & & $\begin{array}{l}a_{c} \\
\text { 2) }\end{array}$ \\
\hline & 柱・梁・壁 & & & $\mathrm{GPa})$ \\
\hline & ・梁・壁 & & ) & 2.4 \\
\hline & 柱・梁・壁 & 39 & ) & 20 \\
\hline \multirow{2}{*}{$\mathrm{N}$} & 柱 . 梁 & $422(41.4 \mathrm{MPa})$ & $15.0(1.47 \mathrm{MPa})$ & \\
\hline & 壁 パ & $351(34.4 \mathrm{MPa})$ & 12.0 & \\
\hline \multirow{2}{*}{ No. F $19 \mathrm{R}$} & 杜 & 428 & 12.5 & $\mathrm{GPa})$ \\
\hline & 壁パネル & $396(38.8 \mathrm{MPa})$ & $10.5(1.03 \mathrm{MPa})$ & 2.47 \\
\hline
\end{tabular}

（）内の数値はSI 単位系で表したものである。
果を考慮してひずみレベルに応じて劣化させた。解析に 用いたコンクリートの材料特性を表一2に示す。コンク リートの一軸圧縮強度 $\left(\sigma_{B}\right)$ にはシリンダー試験によ る試験結果を, コンクリートの引張強度 $\left(\sigma_{t}\right)$ には割裂 強度試験結果を用いた。ただし，コンクリートの引張強 度はシリンダー割裂強度より一般に低い(1)ため, 割裂 強度の $1 / 2$ の值 ${ }^{12)}$ とした。

\section{(2) 鉄 筋}

鉄筋は軸方向のみを負担する板要素としてモデル化し た。架構の主筋は最も外側の要素に板要素として設定し た。ただし，壁パネルはスタブあるいは梁とは鉄筋が不 連続なため壁パネルの鉄筋要素は壁パネル内に定着して いる。壁柱部および境界梁で X 型筋を用いたものでは, $\mathrm{X}$ 型笳を主筋とせん断補強筋の成分に分けて配置して いる。鉄筋の応力ーひずみ関係は図 -7 に示すようにバ イリニア型とした。コンクリートと鉄筋はすべて完全付 着（ひずみが同じ）と仮定した。また，NoＦ１9 およ びNo. FR 19 では水平加力を行って終了した架構の主

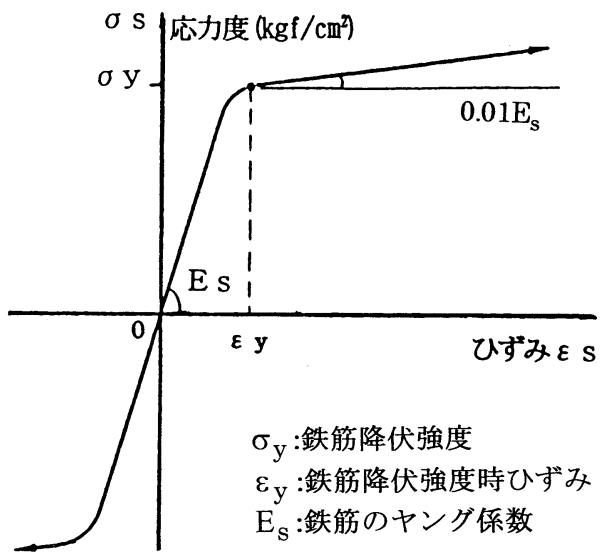

図-7 鉄筋の応力ーひずみ関係

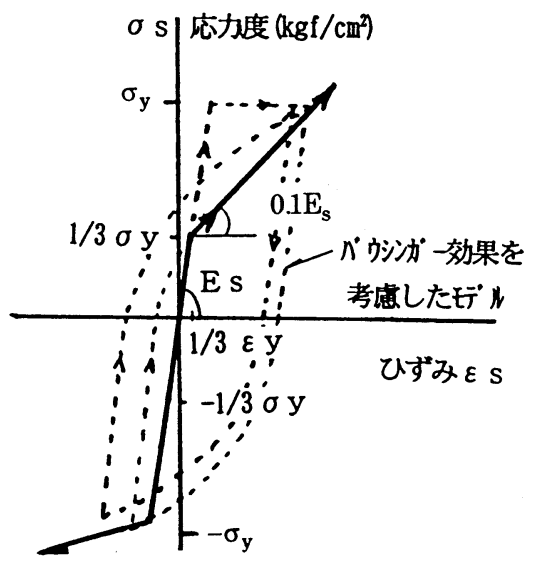

図-8 繰返し加力後のヒンジ域鉄筋の応力ーひずみ関係 
表-2 材料特性

（2）鋼材の機械的性質

(a) 壁パネル単体実験

\begin{tabular}{|c|c|c|c|c|c|}
\hline 種 別 & 径 & $\begin{array}{l}\text { 降 伏 強 度 } \\
\left(\mathrm{kgf} / \mathrm{cm}^{2}\right)\end{array}$ & $\begin{array}{l}\text { 引張 強 度 } \\
\left(\mathrm{kgf} / \mathrm{cm}^{2}\right)\end{array}$ & 試験体名 & 使用部位 \\
\hline \multirow{5}{*}{$\begin{array}{lr}\text { 鉄 } & \text { 筋 } \\
(\mathrm{SD} & 295)\end{array}$} & \multirow{4}{*}{ D 6} & $3870(379 \mathrm{MPa})$ & $5370(527 \mathrm{MPa})$ & No. $2,3,5$ & \multirow{2}{*}{ 壁筋 } \\
\hline & & $4660(457 \mathrm{MPa})$ & $6480(635 \mathrm{MPa})$ & No. 17 & \\
\hline & & $2910(285 \mathrm{MPa})$ & $5500(539 \mathrm{MPa})$ & No. 17 & 壁柱帯筋 \\
\hline & & $3810(374 \mathrm{MPa})$ & $5640(553 \mathrm{MPa})$ & No. 17 & 壁柱主筋 \\
\hline & D 16 & $3510(344 \mathrm{MPa})$ & $5410(531 \mathrm{MPa})$ & No. 17 & $\mathrm{X}$ 型筋 \\
\hline \multicolumn{2}{|c|}{$\mathrm{PC}$ 鋼棒 } & $11800(1160 \mathrm{MPa})$ & $12900(1260 \mathrm{MPa})$ & \multicolumn{2}{|l|}{ 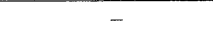 } \\
\hline
\end{tabular}

(b) 耐震壁実験

\begin{tabular}{|c|c|c|c|c|c|}
\hline 種別 & 径 & $\begin{array}{l}\text { 降伏強度 } \\
\left(\mathrm{kgf} / \mathrm{cm}^{2}\right)\end{array}$ & $\begin{array}{l}\text { 引張 強 度 } \\
\left(\mathrm{kgf} / \mathrm{cm}^{2}\right)\end{array}$ & $\begin{array}{l}\text { ヤング係数 } E_{s} \\
\left(10^{6} \mathrm{kgf} / \mathrm{cm}^{2}\right)\end{array}$ & 使用試験体名 \\
\hline \multirow{3}{*}{$\begin{array}{l}\text { 架 } \\
\text { 構 } \\
\text { 主 }\end{array}$} & \multirow{2}{*}{ D 16} & $3620(355 \mathrm{MPa})$ & $5220(512 \mathrm{MPa})$ & $1.91(187 \mathrm{GPa})$ & No. F 3, F 18, F 19 柱梁 \\
\hline & & $3590(352 \mathrm{MPa})$ & $5450(534 \mathrm{MPa})$ & $2.02(198 \mathrm{GPa})$ & No. FR 3, FR 19 柱 \\
\hline & D 19 & $6810(668 \mathrm{MPa})$ & $9050(887 \mathrm{MPa})$ & $2.04(200 \mathrm{GPa})$ & No. FR 3, FR 19 梁 \\
\hline \multirow{3}{*}{$\begin{array}{ll}\text { 壁 } & \text { 柱 } \\
\text { 主 } & \text { 筋 }\end{array}$} & \multirow{3}{*}{ D 10} & $3480(341 \mathrm{MPa})$ & $4770(468 \mathrm{MPa})$ & $1.82(178 \mathrm{GPa})$ & No. F 18 \\
\hline & & $3380(331 \mathrm{MPa})$ & $4760(467 \mathrm{MPa})$ & $1.83(179 \mathrm{GPa})$ & No. FR 19 \\
\hline & & $3510(344 \mathrm{MPa})$ & $4910(481 \mathrm{MPa})$ & $1.86(182 \mathrm{GPa})$ & No. F 3, F 18, F 19 \\
\hline \multirow{2}{*}{$\begin{array}{l}\text { せん断 } \\
\text { 補強筋 }\end{array}$} & \multirow{2}{*}{ D 6} & $2910(285 \mathrm{MPa})$ & $5500(539 \mathrm{MPa})$ & $1.67(164 \mathrm{GPa})$ & No. FR 3, FR 19 柱 \\
\hline & & $3850(378 \mathrm{MPa})$ & $5200(510 \mathrm{MPa})$ & $1.71(168 \mathrm{GPa})$ & No. FR 3, FR 19 梁 \\
\hline 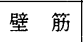 & D 6 & $4660(457 \mathrm{MPa})$ & $6480(635 \mathrm{MPa})$ & $2.04(200 \mathrm{GPa})$ & 全試験体 \\
\hline \multirow{2}{*}{$\mathrm{X}$ 型筋 } & \multirow{2}{*}{ D 16} & $3560(349 \mathrm{MPa})$ & $5150(505 \mathrm{MPa})$ & $1.88(184 \mathrm{GPa})$ & No. F $18, F 19$ \\
\hline & & $3590(352 \mathrm{MPa})$ & $5450(534 \mathrm{MPa})$ & $2.02(198 \mathrm{GPa})$ & No. FR 19 \\
\hline \multirow{2}{*}{$\begin{array}{c}\mathrm{PC} \\
\text { 鋼 棒 }\end{array}$} & $\phi 17$ & $12200(1200 \mathrm{MPa})$ & $13300(1300 \mathrm{MPa})$ & $2.07(203 \mathrm{GPa})$ & No. F $3, \mathrm{~F} 18, \mathrm{~F} 19$ \\
\hline & $\phi 21$ & $11700(1150 \mathrm{MPa})$ & $12800(1260 \mathrm{MPa})$ & $2.05(201 \mathrm{GPa})$ & No. FR 3, FR 19 \\
\hline
\end{tabular}

（）内の数值はSI 単位系で表したものである。

筋が繰り返し加力を受けて降伏状態にあることから，柱 の柱頭および柱脚のヒンジ領域 $(1.5 \mathrm{D}$; D は柱のせ い）および梁のヒンジ領域にある引張側の主筋は，図 -8 に示すように繰返し加力によるバウシンガー効果を 考虑し, 主筋の降伏強度を $1 / 3 \sigma_{y}$ とし, 第二勾配を処 女載荷時の 10 倍とした。

(3) 水平接合部

壁パネルとスタブあるいは梁との接合部は，節点に入 る水平方向の応力および鉛直方向の応力ごとに，図 -9 および図-10に示すように接線バネと法線バネにモデル 化した。図-9 は，接線バネをモデル化したもので，壁 パネル単体実験により求められた水平接合部の平均水平 せん断応力とすべりの関係 ${ }^{2}$ である。水平接合部節点に 作用する鉛直方向応力度の増加により上にシフトするよ うにしている。すなわち，図-9において実線は，コッ ターのせん断力と $\mathrm{PC}$ 鋼棒による初期導入軸方向力の摩 擦力を加えたせん断力を壁パネルの断面積で除した平均 せん断応力 $\tau$ と水平すべり $\mathrm{S}$ の関係である。最大值 $\left({ }_{0} \tau_{\max }\right)$ は,

$$
{ }_{0} \tau_{\max }=0.09 \cdot \lambda \cdot F c+0.7\left(\sigma_{n}\right)
$$

$\lambda:$ コッター面積比 $F c$ : コンクリート圧縮強度 $\sigma_{n}:$ 鉛直圧縮応力度

となり，これを初期設定モデルとする。

初期設定モデルに対して変形の増大により水平接合部 節点の鉊直方向応力度 $\left(\sigma_{n}\right)$ が付加軸力 $\left(\sigma_{a}\right)$ の影響 により増加すると軸方向応力を考虑した $\tau-\mathrm{S}$ モデル は,

$\tau_{\max }=0.09 \cdot \lambda \cdot F c+0.7\left(\sigma_{n}+\alpha \cdot \sigma_{a}\right)$

$\lambda:$ コッタ一面積比 $F c$ : コンクリート圧縮強度

$\sigma_{n}:$ 鉛直圧縮応力度 $\sigma_{a}:$ 付加軸応力度

$\alpha:$ 鉛直圧縮応力度に伴う係数

に移行し，そのモデルから水平せん断応力と水平すべり が求まる。 $\tau_{\max }$ 以降は文献 ${ }^{13)}$ を参考にして下り勾配を 求めている。

また，法線バネには図-10に示すように，めり込みに 対する圧縮剛性と引張剛性（零）を与えている。接線バ ネ $(\mathrm{Kt})$ と法線バネ $(\mathrm{Kn})$ の材料特性を表-3に示す。

(4) 非線形数值計算法

解析は，単調載荷による変位増分法で行い，ひび割れ の発生などによって生じる不釣り合い力は，等価節点荷 


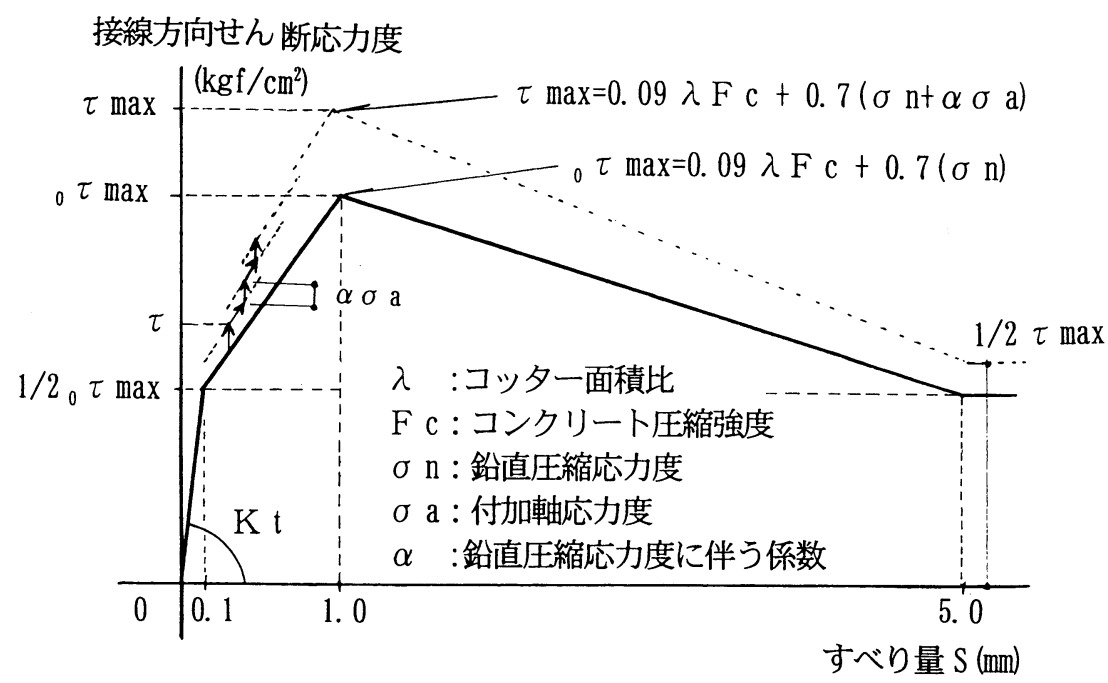

図-9 接線バネモデル

表-3 接線バネ・法線バネ特性

(a) 壁パネル単体

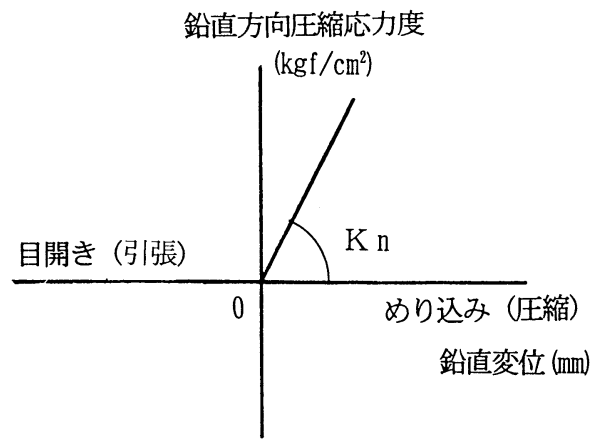

図-10 法線バネモデル

\begin{tabular}{l|c|c|c}
\hline \multirow{2}{*}{ 試験体名 } & \multicolumn{2}{|c|}{ 接線バネ } & 法線バネ \\
\cline { 2 - 4 } & $\begin{array}{c}K t \\
\left(\mathrm{kgf} / \mathrm{cm}^{3}\right)\end{array}$ & $\begin{array}{c}\text { ot } \\
\left(\mathrm{kgf} / \mathrm{cm}^{2}\right)\end{array}$ & $\begin{array}{c}K n \\
\left(\mathrm{kgf} / \mathrm{cm}^{3}\right)\end{array}$ \\
\hline No. 2 & $2060(202 \mathrm{MPa} / \mathrm{cm})$ & $41.2(4.04 \mathrm{MPa})$ & $20000(1960 \mathrm{MPa} / \mathrm{cm})$ \\
\hline No. 3 & $2170(213 \mathrm{MPa} / \mathrm{cm})$ & $43.3(4.25 \mathrm{MPa})$ & $20000(1960 \mathrm{MPa} / \mathrm{cm})$ \\
\hline No. 5 & $2170(213 \mathrm{MPa} / \mathrm{cm})$ & $43.4(4.26 \mathrm{MPa})$ & $20000(1960 \mathrm{MPa} / \mathrm{cm})$ \\
\hline No. 17 & $2420(237 \mathrm{MPa} / \mathrm{cm})$ & $48.4(4.75 \mathrm{MPa})$ & $20000(1960 \mathrm{MPa} / \mathrm{cm})$ \\
\hline ( ) 内の数值は SI 単位系で表したものである。
\end{tabular}

(b) 耐震壁実験

\begin{tabular}{l|c|c|c}
\hline \multirow{2}{*}{\begin{tabular}{c} 
試験体名 \\
\cline { 2 - 4 }
\end{tabular}} & $\begin{array}{c}\text { Kt 接線バネ } \\
\left(\mathrm{kgf} / \mathrm{cm}^{3}\right)\end{array}$ & $\begin{array}{c}0 \tau_{\max } \\
\left(\mathrm{kgf} / \mathrm{cm}^{2}\right)\end{array}$ & $\begin{array}{c}\text { 法線バネ } \\
\left(\mathrm{kgf} / \mathrm{cm}^{3}\right)\end{array}$ \\
\hline No. F 3 & $2430(238 \mathrm{MPa} / \mathrm{cm})$ & $48.6(4.77 \mathrm{MPa})$ & $20000(1960 \mathrm{MPa} / \mathrm{cm})$ \\
\hline No. FR 3 & $2360(231 \mathrm{MPa} / \mathrm{cm})$ & $47.3(4.64 \mathrm{MPa})$ & $20000(1960 \mathrm{MPa} / \mathrm{cm})$ \\
\hline No. F 18 & $2350(230 \mathrm{MPa} / \mathrm{cm})$ & $47.1(4.62 \mathrm{MPa})$ & $20000(1960 \mathrm{MPa} / \mathrm{cm})$ \\
\hline No. F 19 & $2250(221 \mathrm{MPa} / \mathrm{cm})$ & $44.9(4.40 \mathrm{MPa})$ & $20000(1960 \mathrm{MPa} / \mathrm{cm})$ \\
\hline No. FR 19 & $2350(230 \mathrm{MPa} / \mathrm{cm})$ & $47.1(4.62 \mathrm{MPa})$ & $20000(1960 \mathrm{MPa} / \mathrm{cm})$ \\
\hline ( ) 内の数值は SI 単位系で表したものである。
\end{tabular}

重として各変位増分ステップで解放するが, 規定 (10 回）の反復回数を超えても設定した精度（節点力の $5 \%$ ） まで収れんしない場合は, 次のステップに加えるものと した。また, 収れん計算の間は剛性を一定とし, 変位増 分ごとに剛性を更新するものとした。

\section{3. 解析結果亡実験結果の比較}

\section{1 壁パネル単体実験結果との比較}

壁パネル単体実験における破壊形式別の実験結果と解 析結果を比較して, 荷重一変形関係の包絡線を図-11 に, ひび割れ発生状況亡主応力分布状況を図-12 に示 す。両図とも実験と解析結果を比較したものであり, 実
験の結果, 壁パネル脚部がすべり破壊したものが No. 3 , 壁パネルがせん断破壊したものがNo. 2, 壁柱部が曲 げ破壊したものがNo. 17, 壁脚部が曲げ圧壊したものが No. 5 である。

各試験とも, FEM 解析による荷重一部材角関係の包 絡線は実験結果と対応がよく, 最大耐力時部材角もおお むね対応している。また, ひび割れ発生状況之主応力分 布に関しては, 破壊形式別にその特徴が現れている。す なわち, 壁パネル脚部がすべり破壊を示す No. 3 につ いては, 壁パネル中央域のひび割れは少なく, 主応力の 大きさも壁パネルがせん断破壊するNo. 2 に比べて小 さくなっている。No. 2 のパネル部のひび割れ量は多 
く，比較的大きな主応力の分布範囲は壁パネル部長さの 半分以上の幅となっていることが認められる。また, 壁 柱部が曲げ破壊するNo. 17 では，壁柱部にひび割れが 集中しており, 壁パネル脚部が圧壊する No. 5 ではコ ンクリートの破壊が集中する部分の主応力が大きくなっ ており，いずれも実験結果之解析結果の対応がとれてい ることが涊められる。

\section{2 耐震壁実験結果との比較}

耐震壁に関する荷重一層間変形関係の包絡線を解析結 果と実験結果を比較して図-13 に示す。No. F 3 および No. F 18 では解析と実験の結果は最大耐力までよく対 応できているといえる。最大耐力以降は, 解析では発散 してしまい終局の破壊モードを特定することはできてい ない。No. F 19 の解析と実験の結果はおおむね対応し ており，これにより，一度鉄笳が降伏した架構に対して はバウシンガー効果を考虑に入れた図-8に示した鉄筋 モデルを用いることにより実験結果を追跡できるといえ る。

最大耐力時のコンクリートの主応力状態を図 -14 に示 す。No. F 3 では壁パネルの長さのほぼ半分の幅のスト ラット領域の応力レベルが高くなっていることが認めら れる。No. F 18 では壁パネル中央の壁柱部に応力が集 中していることが認められる。また，NoＦ 19 では シースに沿う部分のコンクリートのひずみが大きくなっ ていることが忍められる。

No. F 18 および No. F 19 の壁パネルの主応力状態 は, 開口の影響を受けて No. F 3 とは異なり応力の伝 達が妨げられる結果となっており，これにより耐震壁の 耐力に差異が生じているものと考えられる。

\section{3 耐震壁壁パネル横筋のひずみ量の推移}

No. 3, No. F 3, No. FR 3 の壁パネル横筋のひずみ 量の層間変形角ごとの推移を実験結果と解析結果を比較 して図-15に示す。同図の縦軸は鉄筋のひずみを，横軸 はひずみ測定位置を示している。壁パネル脚部では，圧 縮域となる領域の横筋のひずみ（図中実線の円または棈 円で囲んだ範囲）が大きくなり，引張域となる領域の横 筋のひずみ（図中破線の円または楕円で囲んだ範囲）は 小さくなることが，解析および実験結果から認められ る。これは，壁パネルの压縮ストラットとそのストラッ 卜の水平成分の力を分担する横筋のひずみ量とが対応し ており，ストラットの形成されている壁パネル脚部圧縮 域および中央レベルの中央域のひずみ量が大きくなって いることを示しているものである。壁パネル中央レベル のひずみの推移は，最も外側に配置された $\mathrm{PC}$ 鋼棒間で 囲まれた範囲のひずみが大きく出ており，この傾向は実 験值および解析值双方において認められる。
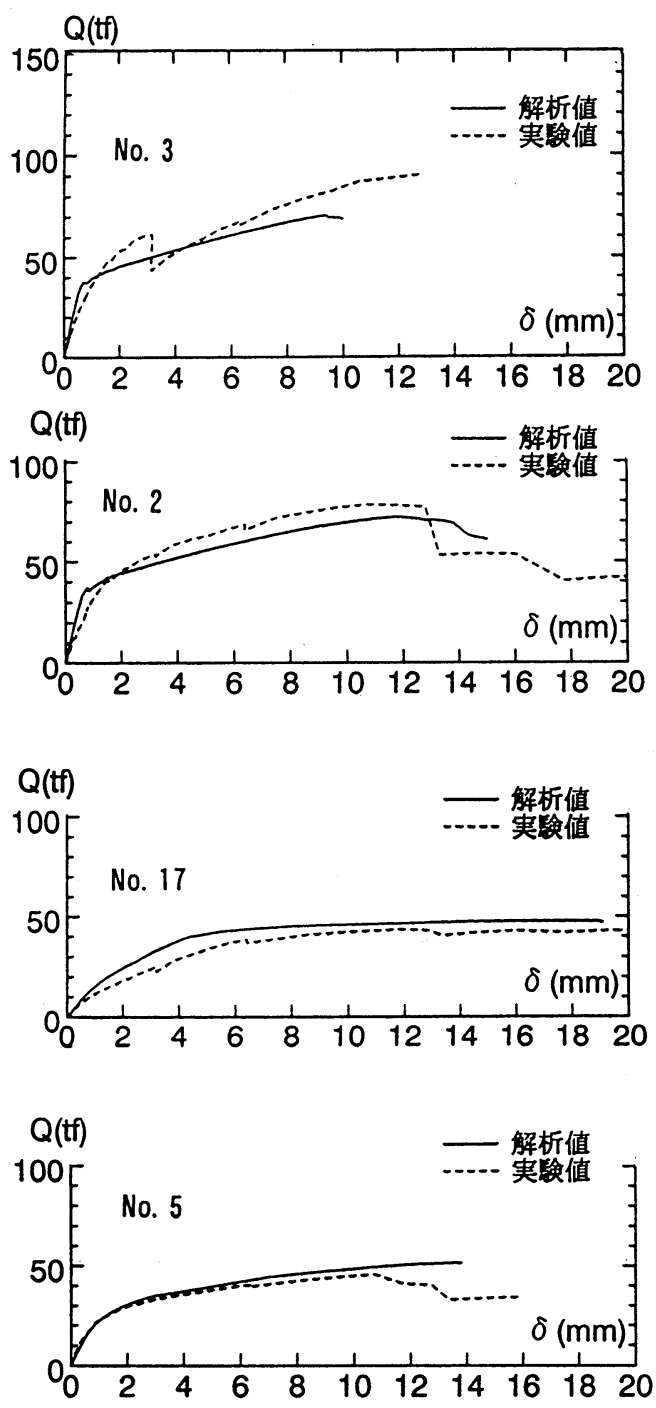

図-11 荷重-変形関係の包絡線（壁パネル単体実験）

\section{4. 耐震壁に与える架構および PC 鋼棒の 影響}

\section{1 水平接合部の目開きおよびすべり性状}

No. F 3, No. F 18, No. FR 3 の壁パネル脚部の目 開きおよびすべりの層間変形角ごとの推移を, 実験結果 と解析結果を比較して図-16 に示す。同図において点線 区間が壁パネル長さを示しており，目開きおよびすべり 量は試験体寸法の 100 倍にして表示している。

同図より壁パネルがすべり破壊を示したNo．Ｆ３は， 層間変形角の増大に伴い，壁パネル脚部の圧縮域から引 張域にかけて目開き量が直線的に増大することが認めら れ，解析值も実験値をよく追跡していることが認められ 

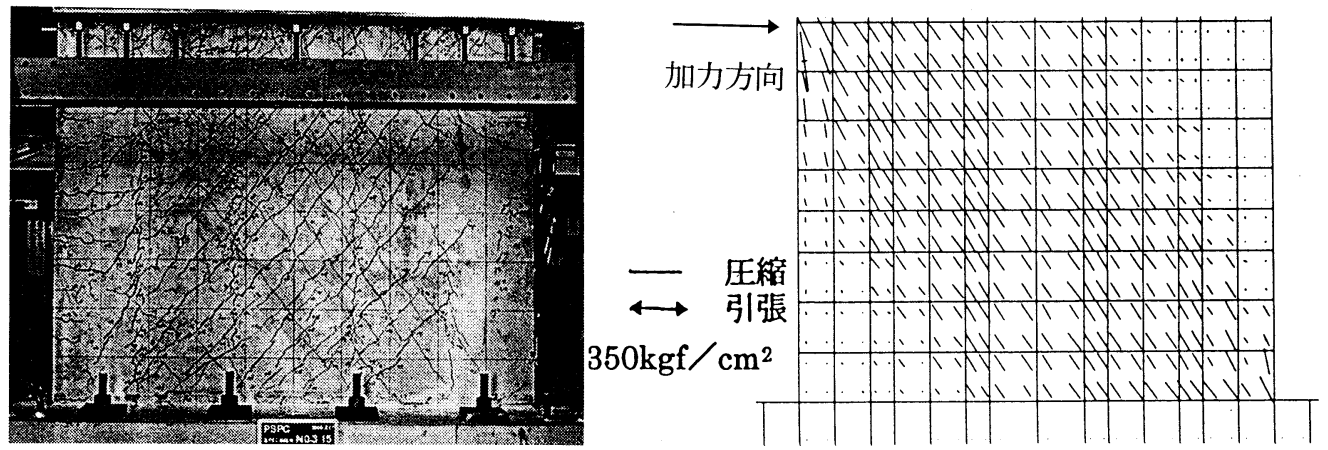

(a)すべり破壊形式 (No. 3)
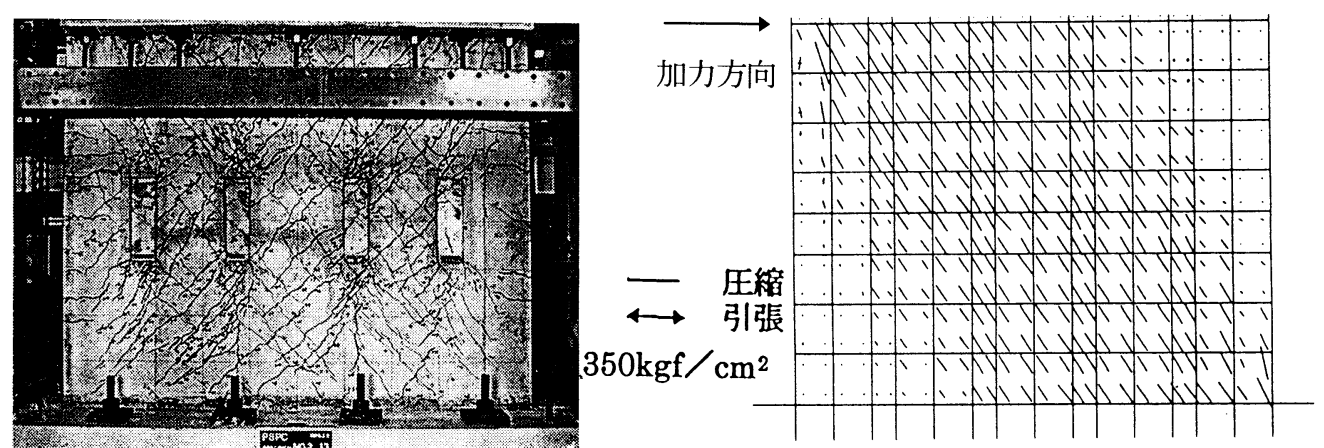

(b) せん断破㯰形式 (No. 2)
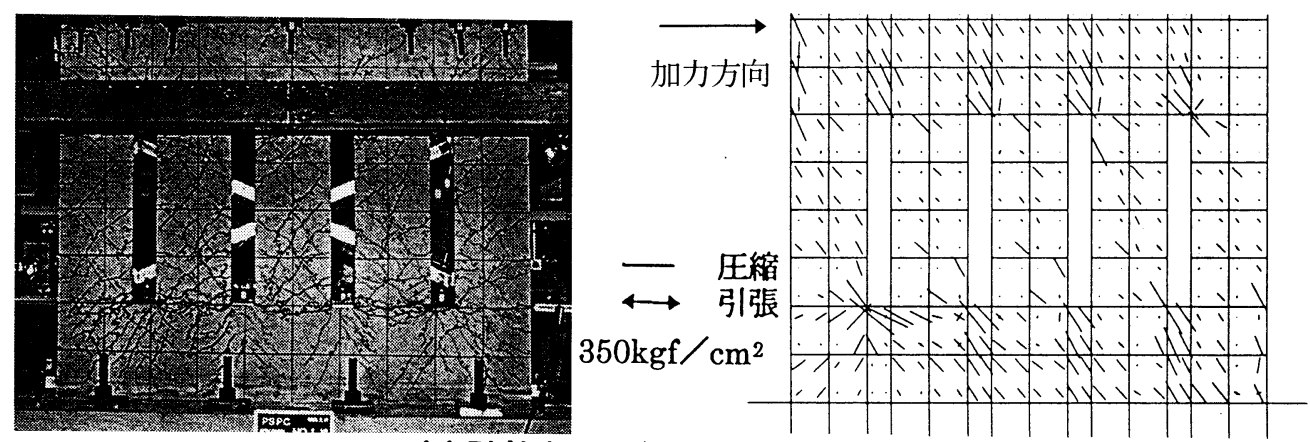

(c) 壁柱部曲け破壊形式 (№. 17)
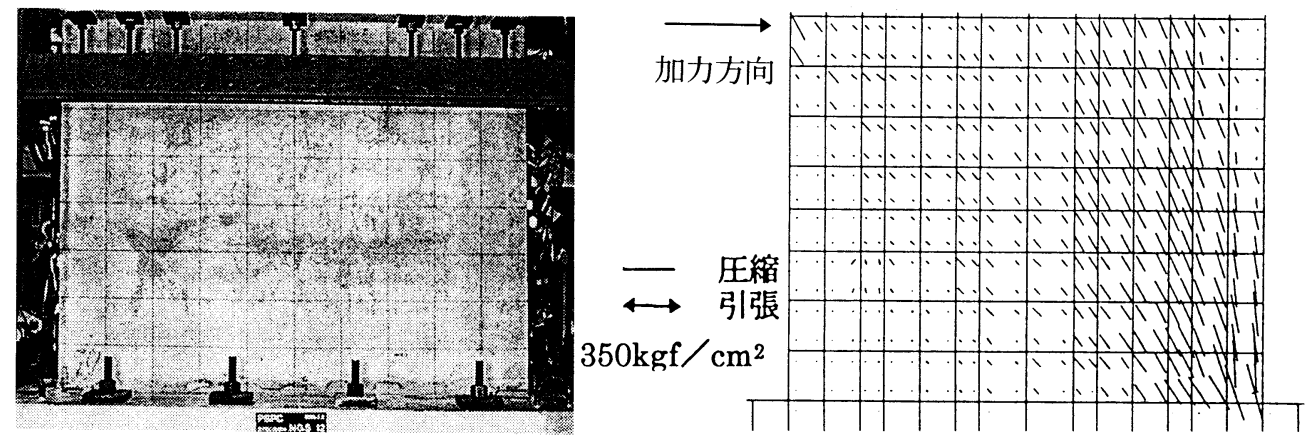

(d) 壁脚部曲げ圧壊形式 (No. 5)

図-12 ひび割れ発生状況と主応力分布状況（最大耐力時） 

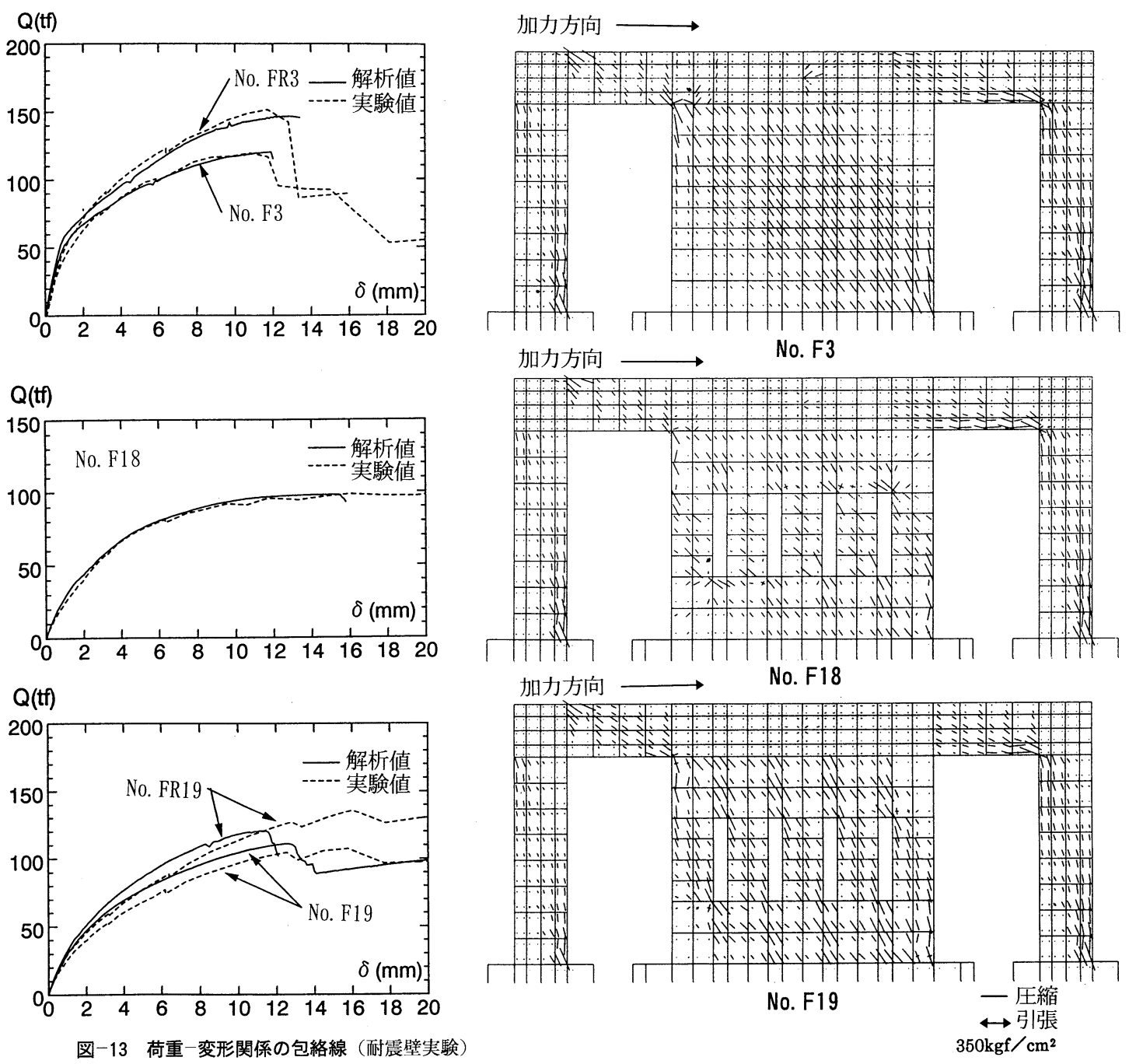

図一14 コンクリートの主応力状況（最大耐力時）

る。これに対して, No. FR 3 は, 架構の耐力および $\mathrm{PC}$ 鋼棒の剛性を高めたものであるが, 壁パネルが押さ え込まれて目開き量が抑えられている実験結果が解析結 果からも認められる。No.F 18 は, PC 鋼棒を連結して いない試験体であるが, 目開きは壁パネルの引張側の PC 鋼棒に集中している。また, No. F 18 はすべりもほ とんど発生しておらず, 実験值と解析值はおおむね一致 している。

これらの結果より, 実験により求めた平均的な壁パネ ル水平接合部のせん断応力と水平すべりの関係を解析モ デルに取り込むことで水平接合部がすべり破壊する耐震 壁の破壊形式を推定できるものと考えられる。

\section{$4.2 \mathrm{PC}$ 鋼棒のひずみ推移}

No. 3, No. F 3, No. FR 3 の壁パネルに挿入したPC
鋼棒の層間変形角の増大に伴うひずみ変化量を軸力に換 算し, 解析值と実験結果を比較して図-17に示す。

No. 3 は単体実験のものであり, 壁パネルの回転を拘 束し壁パネル上の加力梁は下スタブと平行移動するよう に加力している。そのため, PC 鋼棒の軸力は最大耐力 時を除いて, 変形角の増大に伴い 4 本ともほぼ等量に増 大している。FEM の解析值も等量となっている。これ に対して, No. F 3 およびNo. FR 3 は水平加力により 壁パネルが回転を生じるため回転の圧縮側の PC 鋼棒の 軸力量は引張側よりも小さくなっている。この傾向は, 実験結果および解析結果とも同様であり, 架構の耐力が 高く PC 鋼棒の断面積を大きくした No. FR 3 の方が PC の鋼棒の軸力量は大きく, No. F 3 よりも高い付加 軸力が作用していたと考えられる。 

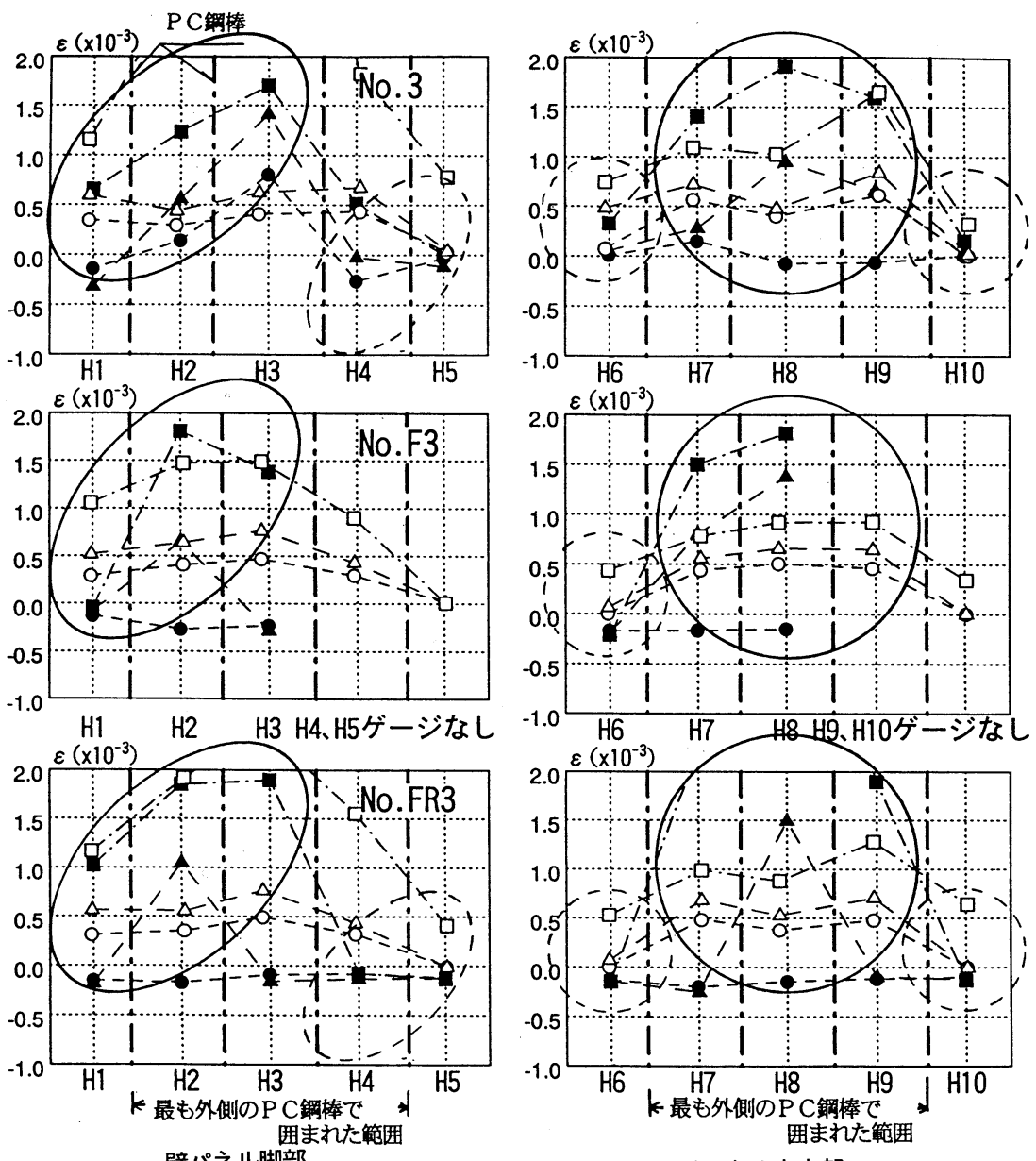

壁パネル中央部

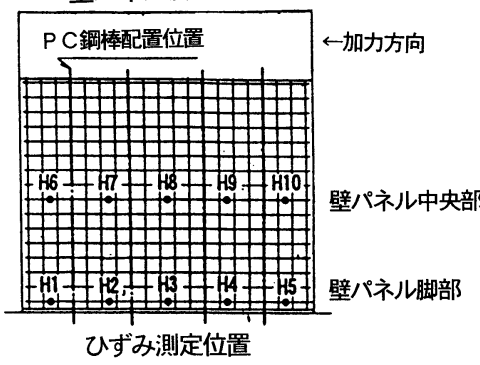

- $-2.0 \times 10^{-3} \mathrm{rad}$.（実験值）

$\rightarrow-4.0 \times 10^{-3} \mathrm{rad}$. (実験值)

$\rightarrow-8.0 \times 10^{-3} \mathrm{rad}$. (実験値)

$-0-2.0 \times 10^{-3} \mathrm{rad}$. (解析値)

$\triangle-4.0 \times 10^{-3} \mathrm{rad}$. (解析値)

- $8.0 \times 10^{-3} \mathrm{rad}$. (解析値)

実線の円または棈円はひずみの大きい範囲を示す 破線の円または棈円はひずみの小さい範囲を示す

図-15＼cjkstart壁パネル横筋のひずみ推移図

No. 3, No. F 3, No. FR 3 の壁パネルに挿入したPC 鋼棒の付加軸力に関しては, 解析值は実験結果をよく追 跡できていると考えられる。

\section{3 壁パネル上梁の回転}

No. F 3, No. F 18, No. FR 3 の壁パネル上部の梁 の回転角と層間変形角の関係について, 解析結果と実験 結果と比較して図-18に示す。

壁パネルの回転は壁パネル上部の梁の回転量で示して
いる。実験結果では，壁パネルに開口のない No. F 3 お よび No. FR 3 層間変形角の増大に伴い No. F 18 より も大きな回転変形を生じている。これは，No.F 18 の 壁パネルの剛性が開口のために低下したためと考えられ る。実験值と比べて解析值の方が比較的小さい回転量と なっているものの，架構の耐力が高く $\mathrm{PC}$ 鋼棒の径を太 くした No. FR 3 が架構の耐力が低く PC 鋼棒の径の 細いNo. F 3 よりも小さな回転となっていることや, 


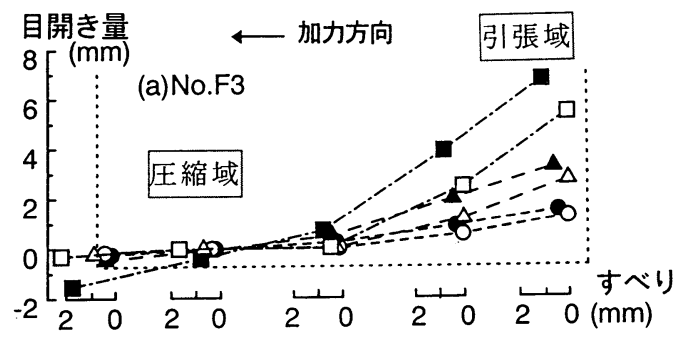

付加軸力(tf)

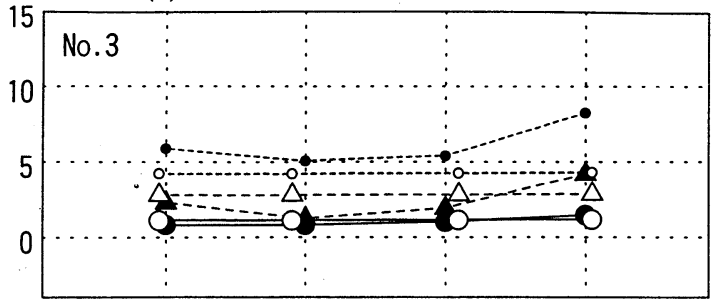

目開き量
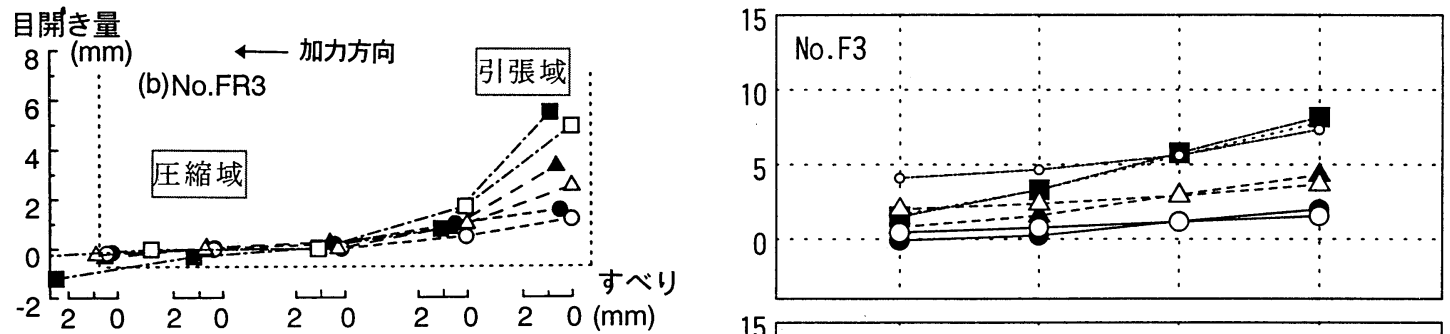

目開き量
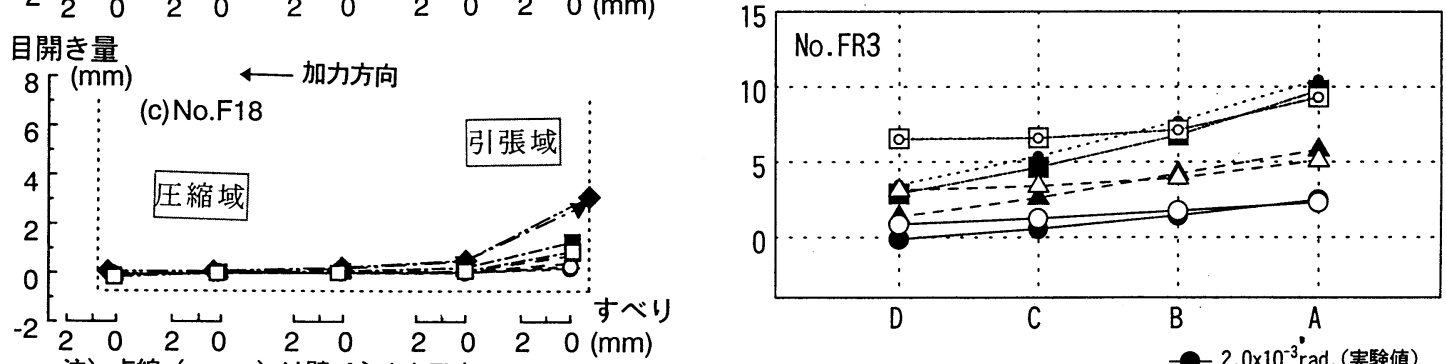

注）点線（- - - ) は壁パネルを示す

すべり、目開き量は試験体寸法の 100 倍

解析値

- 0 - $2.0 \times 10^{-3} \mathrm{rad}$.

$-\Delta-4.0 \times 10^{-3} \mathrm{rad}$.

$-\square-8.0 \times 10^{-3} \mathrm{rad}$.

$-\nabla-10.0 \times 10^{-3} \mathrm{rad}$.

$\checkmark 13.3 \times 10^{-3} \mathrm{rad}$.

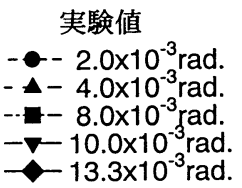

図-16 壁パネル脚部の目開きおよびすべり推移図

開口のないNo. FR 3 およびNo. F 3 に比べて開口が ある No. F 18 の回転量がかなり小さな值となっている ことは, 実験結果と同様に解析結果においても認めら れ, 実験により確認された耐震壁の破壊形式の違いを解 析的にも追跡できることが認められる。

\section{5. まと め}

本研究では, プレキャスト壁パネルと梁とを $\mathrm{PC}$ 鋼棒 により圧着接合する場合の壁パネルが組み込まれた耐震 壁の最大耐力に関する解析的検討を行った。

その結果, 以下の知見が得られた。

（1）一度主筋が降伏した架構に対しても，バウシン ガー効果を考慮に入れた材料定数を用いることにより実 験結果を追跡できる。

（2）実験により求めた壁パネル水平接合部のせん断 応力と水平すべり関係のモデル化を用いることで, 解析

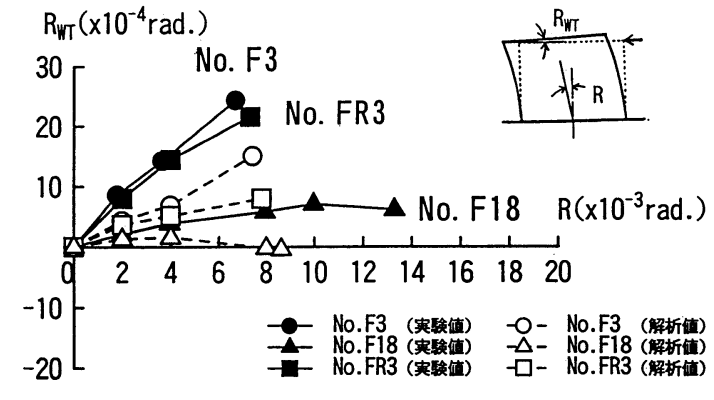

図一18壁パネルの回転角推移図

的に壁パネル脚部がすべり破壊する破壊形式を推定でき る。

（3）壁パネルのせん断力は壁パネルの対角線方法に 流れる圧縮ストラットにより伝達されると考えられ, 最 も外側に配置した PC 鋼棒間のコンクリートの主応力や 横筋のひずみが他と比べて実験と同様に解析においても 
大きくなることが認められた。

（4）本論で使用した解析手法は, 壁パネル単体や耐 震壁の実験結果を荷重一変形関係および最大耐力から, よく追跡できるものである。

（５）壁柱部が曲げ降伏する耐震壁の変形限界は解析 的に追跡できておらず今後の課題である。

[謝 辞] 本研究の遂行に際し, 研究計画から実施に わたり終始貴重なご助言, ご指導およびご協力をいただ きました, フドウ建研の皆様方に深くお礼申し上げま す。

\section{参 考 文 献}

1）加治喜久夫・望月 重・東浦 章・柳沢 学・柳瀬高仁 ・竹田清二・大野由洋：プレストレスを利用したプレ キャスト耐震壁の研究 (その 1 11), 日本建築学会大会 学術講演梗概集 (C-2), pp. 961 964, pp. 953〜956, 1995, 8, pp. 907〜914, 1996. 9 および同 pp. 895〜900, 1997. 9

2) 柳沢 学・望月 重・東浦 章・斎藤文孝: プレストレ スを利用して梁に圧着した壁パネルの水平接合部のすべ り強度に関する実験的研究, 日本建築学会構造工学論文 集 Vol. 43 B, pp. 227〜237, 1997. 3

3) 柳沢 学・望月 重・東浦 章・斎藤文孝: プレストレ スを利用して梁に圧着した壁パネルの最大耐力, コンク リート工学論文集 Vol. 8, No. 2, pp. 91〜100, 1997. 7

4) 柳沢 学・望月 重・東浦 章・斎藤文孝: プレストレ スを利用して梁に圧着された壁パネルが組み込まれた架 構の最大耐力に関する実験的研究, コンクリート工学論 文集 Vol. 9, No.1, pp. 113 122, 1998. 1

5）堤 英明-東浦 章 - 佐藤和英 - 近藤吾郎：有開口高配
筋耐震壁のせん断終局強度に関する研究，コンクリート 工学年次論文報告集 Vol. 10-3, pp. 367 372, 1988

6) Darwin, D. and Pecknold, D. A. W. : In Elastic Model for Cyclic Biaxial Loading of RC, Univ. of Illinois, July, pps 169, 1974

7）宮下 丘・武藤 清・津川恒久・清水弘道 : F. E. M. による鉄筋コンクリート部材の弾塑性解析（その 1 解析 法), 日本建築学会大会学術講演梗概集, pp. 735 736, 1971. 11

8) Saens, L. p., Disc. of "Equation for the StressStrain Curve of Concrete," by Desayi and Krishnan. Journal ACI, Proc. V. 61, No. 9, Sept., pp. 1229 1235, 1964

9) Vladimir Cervenka : Constitutive Model for Cracked Reinforced Concrete, ACI Journal, November-December, pp. 877 882, 1985

10) Helmut B. Kupfer and Kurt H. Gerstle : Behavior of Concrete Under Biaxial Stress, ASCE-EM, Augsut, pp. 853 866, 1973

11) Collins, M. P. and Vecchio, F. : Modified Compression Field Theory for Reinforced Concrete Element Subjected Shear, ACI Joural, pp. 219 231, 1986. 3-4

12）松戸正士・張 愛暉・野口 博: RC 高層壁式ラーメン 構造の壁柱の非線形解析 (その 1 ), 日本建築学会大会学 術講演梗概集 C, pp. 847 848, 1989

13）高見信嗣・望月 重・小林高志・吉岡研三 : プレキャス 卜連層耐震壁の接合笳の効果に関する解析, 日本コンク リート工学年次講演会論文報告集 Vol. 14-No. 2, pp. 837 842, 1992

14）日本建築学会 : 壁式プレキャスト構造の鉛直接合部の挙 動と設計法, $2.3 \mathrm{~S}$ 型加力試験 (正負繰り返し加力), pp. $25 \sim 42,1989.4$

（原稿受理年月日：1998 年 1 月 12 日）

\section{An Analytical Study on Maximum Strength of the Shear Wall with Precast Concrete Wall Panel Using Prestressing for the Joint of Wall to Beam}

By Manabu Yanagisawa, Shigeru Mochizuki, Akira Higashiura and Fumitaka Saitoh

Synopsis This paper addresses an analytical study on the maximum strength of the shear wall in which precast concrete wall panel is inserted, which is connected with the upper and lower beams using prestressing, and is not connected with the columns of the both sides. The load-deformation behaviors of wall panel and shear wall have been demonstrated through the numerical simulations using by the following slip model. The slip model for the joints of wall to beam is taken account of the actual phenomenon, which shows that the axial load changes in response to the lateral deformation of specimen. The analyzed results of the load-deformation behaviors show a good agreement with experimental ones, including the failure mode and the strength of the specimens, which are classified to three typical failure modes, slip failure at horizontal joint of wall panel to beam, flexural failure at the remained wall part around openings of wall panel and shear failure of wall panel.

Keywords : precast concrete wall panel, prestressing, shear wall, FEM analysis, slip model 